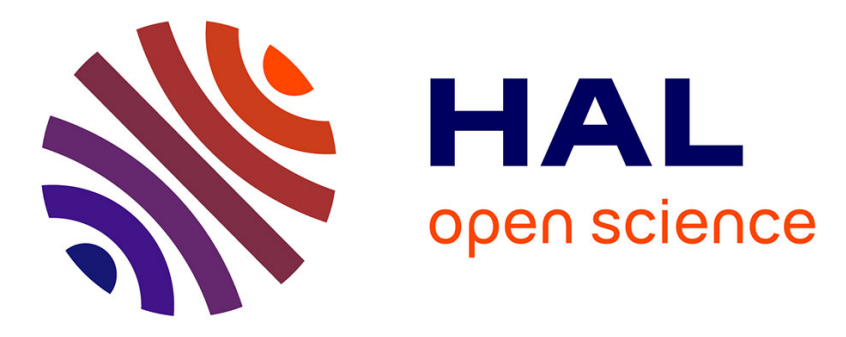

\title{
On the geoelectrical characterization of an old landfill cover
}

Véronique Naudet, Fanny Genelle, Michel Dabas, Colette Sirieix, Joëlle Riss, Stéphane Rénié, Bruno Dubéarnes, Philippe Bégassat

\section{To cite this version:}

Véronique Naudet, Fanny Genelle, Michel Dabas, Colette Sirieix, Joëlle Riss, et al.. On the geoelectrical characterization of an old landfill cover. EAGE Near Surface 2011, the 17th European Meeting of Environmental and Engineering Geophysics of the Near Surface Geoscience Division of EAGE, Sep 2011, Leicester, United Kingdom. hal-00616400

\section{HAL Id: hal-00616400 https: / hal-brgm.archives-ouvertes.fr/hal-00616400}

Submitted on 15 Sep 2011

HAL is a multi-disciplinary open access archive for the deposit and dissemination of scientific research documents, whether they are published or not. The documents may come from teaching and research institutions in France or abroad, or from public or private research centers.
L'archive ouverte pluridisciplinaire HAL, est destinée au dépôt et à la diffusion de documents scientifiques de niveau recherche, publiés ou non, émanant des établissements d'enseignement et de recherche français ou étrangers, des laboratoires publics ou privés. 


\title{
On the geoelectrical characterization of an old landfill cover
}

\author{
Naudet V. ${ }^{1}$; F. Genelle ${ }^{2,3}$, M. Dabas ${ }^{4}$, C. Sirieix ${ }^{2}$, J. Riss ${ }^{2}$, S. Renie ${ }^{3}$, B. Dubearnes ${ }^{5}$, P. Bégassat ${ }^{6}$ \\ ${ }^{2}$ Université Bordeaux 1, I2M-GCE, B18, Avenue des facultés, 33400 Talence, France \\ ${ }^{3}$ HYDRO INVEST, 514 route d'Agris, 16430 Champniers, France; \\ ${ }^{1}$ BRGM, 3 avenue Claude Guillemin, 45060 Orléans, France; \\ ${ }^{4}$ GEOCARTA, 16 rue du sentier, 75002 Paris, France \\ ${ }^{5}$ EAUGEO, 1570 route des Pyrénées, 40230 Orx, France \\ ${ }^{6}$ ADEME, 20 avenue du Grésillé, BP 90406, 49004 Angers cedex 1, France
}

\section{Abstract}

Two geoelectrical methods were used to characterize the state of an old French landfill cover. The objectives were to locate different materials used for the covering such as clay material or geomembrane and to identify heterogeneities that could be linked to possible defects in the cover due to fractures or cracks. These damages can induce preferential water pathways and unusual increase of leachate within the waste mass. The geoelectrical methods used were the electrical resistivity cartography with an Automatic Resistivity Profiling (ARPC) and the Self Potential method (SP). Results have put in evidence three distinct zones with different geoelectrical signatures that are correlated with three different phases of landfill covering. ARP also seems to have detected the presence of geomembrane installed all around the old landfill to improve its stability and geodrains over two closed alveoli. Local differences in apparent resistivity and self-potential signals have also been identified and could result in default in the clay cover due to thickness variations but also in different lithology, compaction and water content.

\section{Introduction}

To minimize infiltration of precipitation and the accumulation of contaminant groundwater within a landfill, impermeable barriers such as compacted clay or geocomposite are covering the overall waste storage. Although ideal barriers are composed of a continuous impermeable clay layer and a geocomposite, real covers are often fractured and eroded due to mechanical, climatic and hydraulic stresses acting on its surface or even be damaged during its laying. These damages can induce an escape of landfill gases and creation of leachate through infiltration of surface water. Geophysical methods would be a good way to detect anomalies due to preferential water pathways and unusual increase of leachate within the waste mass. Currently, as leachate is highly electrically conductive, geophysical methods are mainly used to trace the migration of leachate inside and away from the landfill (Naudet et al., 2004; Guérin et al., 2004). Little attention and few published studies have used geophysical methods to evaluate water recharge through the landfill cap (Carpenter et al., 1991; White and Barker, 1997; Guyonnet et al., 2003; Cassiani et al., 2008). Our goal was to test the feasibility of the electrical resistivity cartography with an Automatic Resistivity Profiling (ARP○) and the Self Potential method (SP) to improve the knowledge of an old French landfill cover.

\section{Methods}

The self-potential (SP) method is a passive electrical method measuring the natural electrical potential at the ground surface with non-polarisable electrodes. It aims at detecting potential changes linked to a natural overload of underground electric charges. These charges are likely to be linked to in-body fluids circulation through the electrokinetic coupling effect, electrochemical coupling like diffusion of ionic species, and oxide-reduction reactions (i.e. Jouniaux et al., 2009). In particular, due to the general inhomogeneity of the subsoil, the SP sources can be distinguished between primary and secondary charge polarizations. The primary sources are associated with the electrokinetic fluid flow through rock pores and fissures, while the second sources are correlated to the distribution of electric charges, induced by the primary sources, along resistivity discontinuities. As concerns the landfill covers, we expect to detect sources mainly due to electrokinetic effect and electrical contrasts separating different kinds of cells or to locate fractures or cracks in the cover that facilitate surface water infiltration. The ARP technique uses a patented multi-electrode device in which wheel-based 
electrodes are inserted in the ground and rolled along the surface (Dabas, 2009). The device is a Vshaped multipole system with one transmitting dipole and three receiving dipoles. The length of the current dipole is fixed and equal to $1 \mathrm{~m}$, while the length of the receiving dipoles increased from 0.5 to 1.00 and $1.70 \mathrm{~m}$ respectively with their distance from the transmitter. The system is attached to a quad bike, which facilitates rapid data acquisition. Use of differential GPS navigation within the system enables accurate surveying. Continuous electrical soil mapping is carried out at three different theoretical depths below ground surface level. Apparent electrical resistivity data are then presented in the form of three maps corresponding to the length of the different measuring dipoles. These maps represent the cumulative volume contribution of the soil from top to the three increasing pseudodepths of investigation.

\section{The studied site}

The studied site has been exploited from 1979 to 1998 with around 600000 tons of municipal waste stored without compaction during this period and composed of oversized waste, raw wastes, crushed and compostable household waste. These wastes form a dome of $10 \mathrm{~m}$ height. From February to April 2002 , wastes from the eastern part have been removed and replaced over the western part of this dome (from zone 3 to zone 1 and 2, fig.1.a). Contrary to the first storage, these wastes were intensely compacted by layers of $50 \mathrm{~cm}$. The cells of the northern part of this zone were dedicated to exclusively compacted wastes stored since 2002 (zone 3, fig.1.a). Therefore, the landfill site comprises three main zones: 1) a zone mainly composed of non-compacted wastes covered before $2002,2)$ a zone composed of around $7 \mathrm{~m}$ of non-compacted wastes overlain by $6 \mathrm{~m}$ of compacted waste covered after 2002, and 3) a zone of only compacted wastes covered at the end (fig. 1.a). Except for zone 3, the covering layer was composed of a $1 \mathrm{~m}$ clayed material overlain by a $0.50 \mathrm{~m}$ topsoil layer. For stability reasons, in the earth banks, the clay has been replaced by a geomembrane overlain by topsoil and anchored at the top of the slopes under the clayey layer (fig. 1.b).

The geophysical measurements were performed in June 2009. Around 440 self-potential data were obtained each $10 \mathrm{~m}$ with $\mathrm{Pb} / \mathrm{PbCl}_{2}$ non-polarizable electrodes. The ARP measurements covered the overall site with a point every $10 \mathrm{~cm}$ along profiles separated by $2 \mathrm{~m}$. Two other closed alveoli covered more recently with geomembrane bands were also prospected with a profile spacing of $1 \mathrm{~m}$. (fig.1.a).

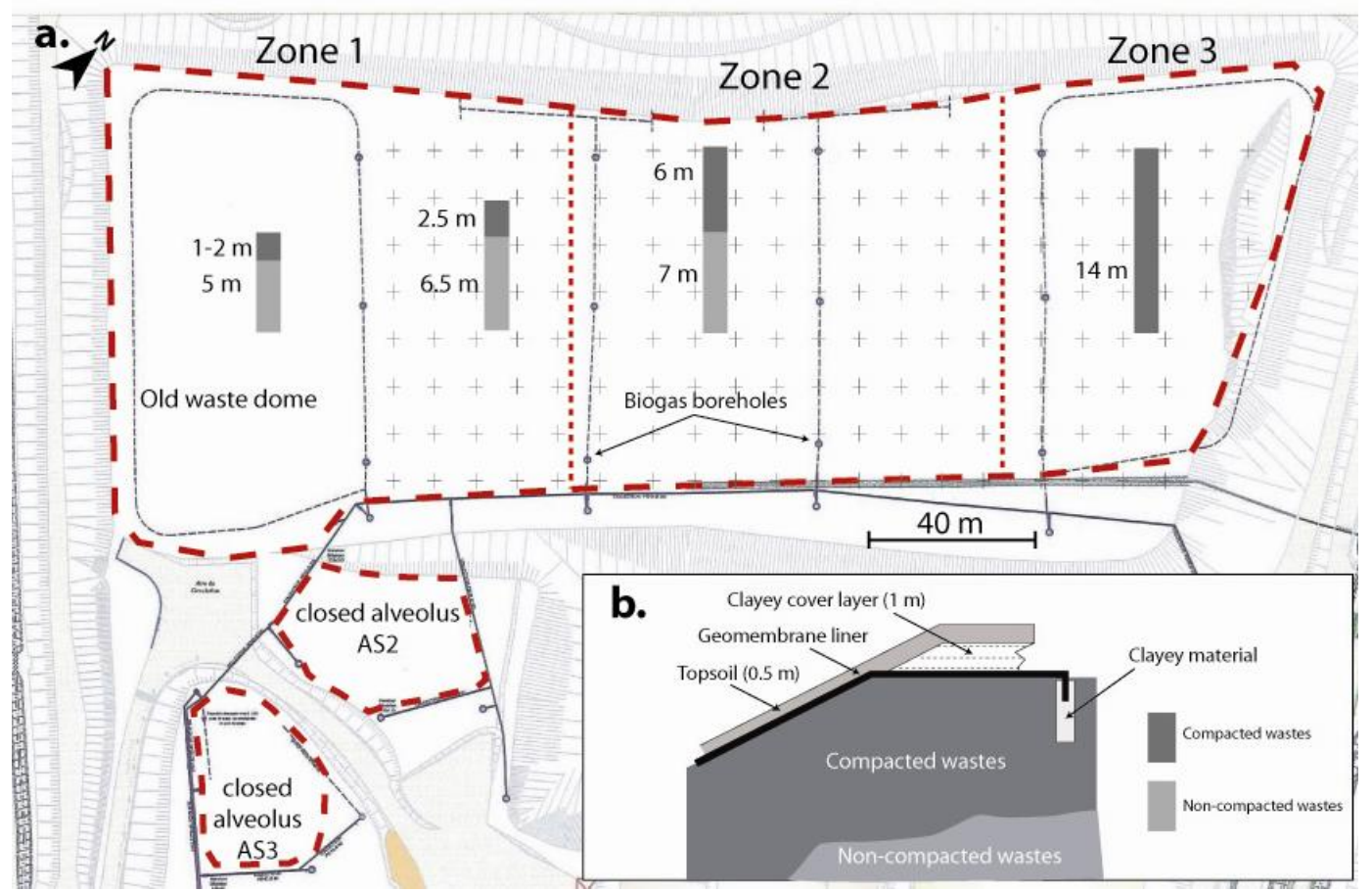

Figure 1 a. Presentation of the studied municipal landfill with location of the three zones in the old waste dome covered at different dates and the two closed alveoli (AS2 and AS3). ARP measurements 
were performed inside the red dotted areas. Crosses indicate SP points. $b$. Cross-section of the western earth bank.

\section{Results}

The apparent electrical resistivity data obtained with the ARP technique are presented in the form of horizontal pseudo-depth slices obtained at three different measuring dipole lengths $(0.5,1$ and $1.70 \mathrm{~m})$ on figure 2. The maps obtained on the old landfill outline the three zones covered at different dates. From zone 3 (more recent) to zone 1 (the oldest), the apparent electrical resistivity decreases. This could be due to a decrease of the clayey cover layer thickness but also differences in the type of clay used, its compaction and also in water content. The more conductive zones $(<5 \mathrm{Ohm} . \mathrm{m})$ could reflect the influence of the very conductive waste on the measurement and therefore reflect a less important cover layer thickness. The three maps show more resistive zones (>50 Ohm.m) all around the landfill and mainly in zone 3. These zones could be attributed to the presence of geomembrane as it is electrically insulating, which were installed in the earth banks and anchored at the top of the slopes under the clayey layer for stability reasons (fig. 1.b). Note also that the electrical signature of this geomembrane, which tends to decrease with the investigation depth, is more important for the shallower measuring dipole length $(0.7 \mathrm{~m})$. This could indicate that the topsoil plus clayey cover layer thickness could be less than $1.5 \mathrm{~m}$ as initially installed (fig.1.b). ARP measurements performed on the two adjacent alveoli outline distinguished more resistive lines with around $5 \mathrm{~m}$ width, which are detected since the first investigation depth. These lines seem to correspond to geodrains installed above $0.5 \mathrm{~m}$ of topsoil.

The self-potential map presented on figure 3 also shows a contrast between zone 1 characterized by more elevated SP values and zone 3. This difference could be due to the electrical contrast between these zones due to water content and thickness variations of the clayey cover layer. The SP map also identified negative anomalies $(>8 \mathrm{mV}$ in absolute value) in the resistive zones identified by the ARP method on the edge of the landfill and that could be attributed to the geomembrane. 


\section{Near Surface}

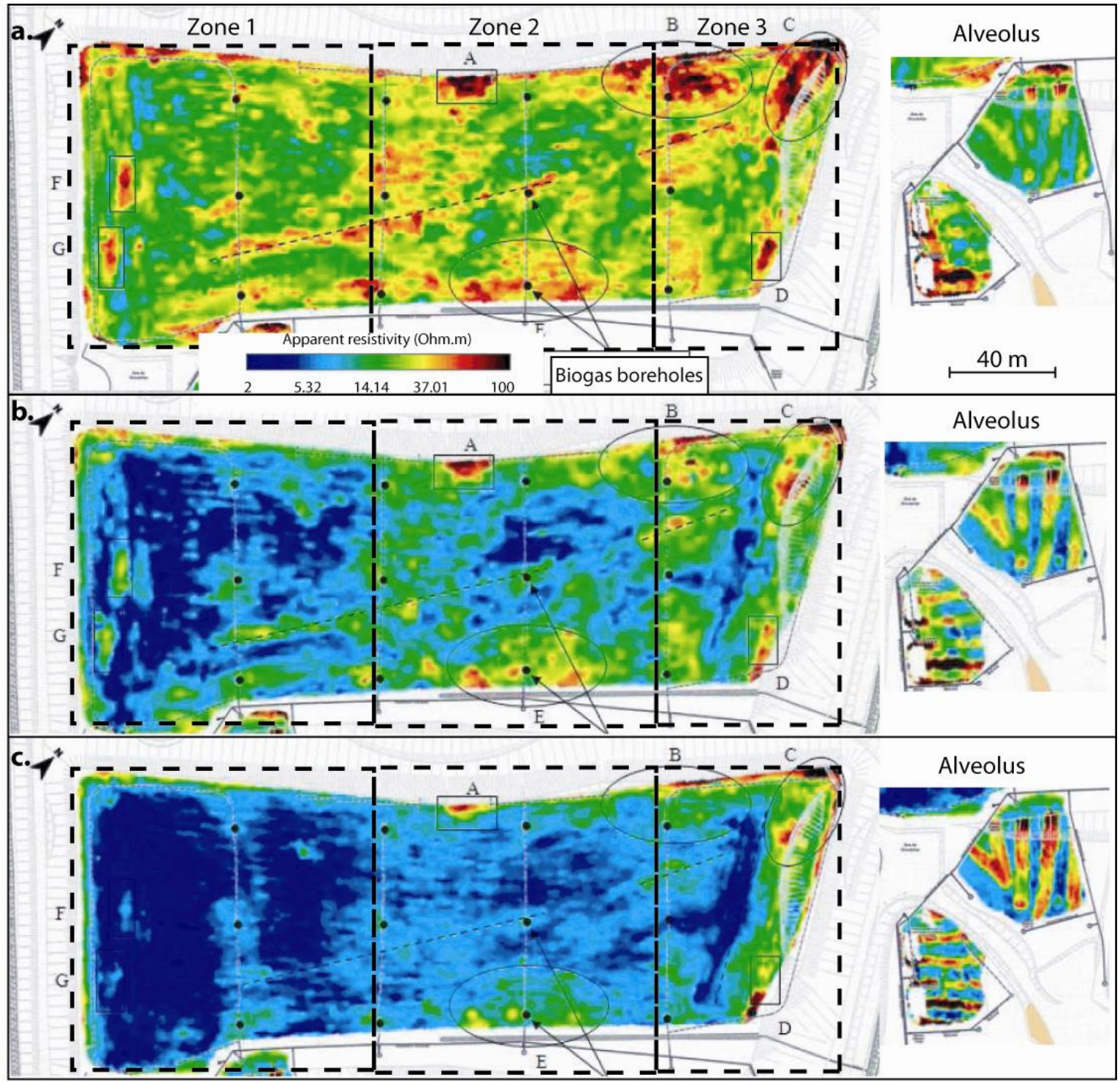

Figure 2 Apparent electrical resistivity maps obtained with the ARP technique on the old landfill and the two adjacent alveoli (receiving dipole length of $0.5 \mathrm{~m}(\mathrm{a}$.), $1 \mathrm{~m}(\mathrm{~b}$.$) and 1.7 \mathrm{~m}(\mathrm{c}$.)

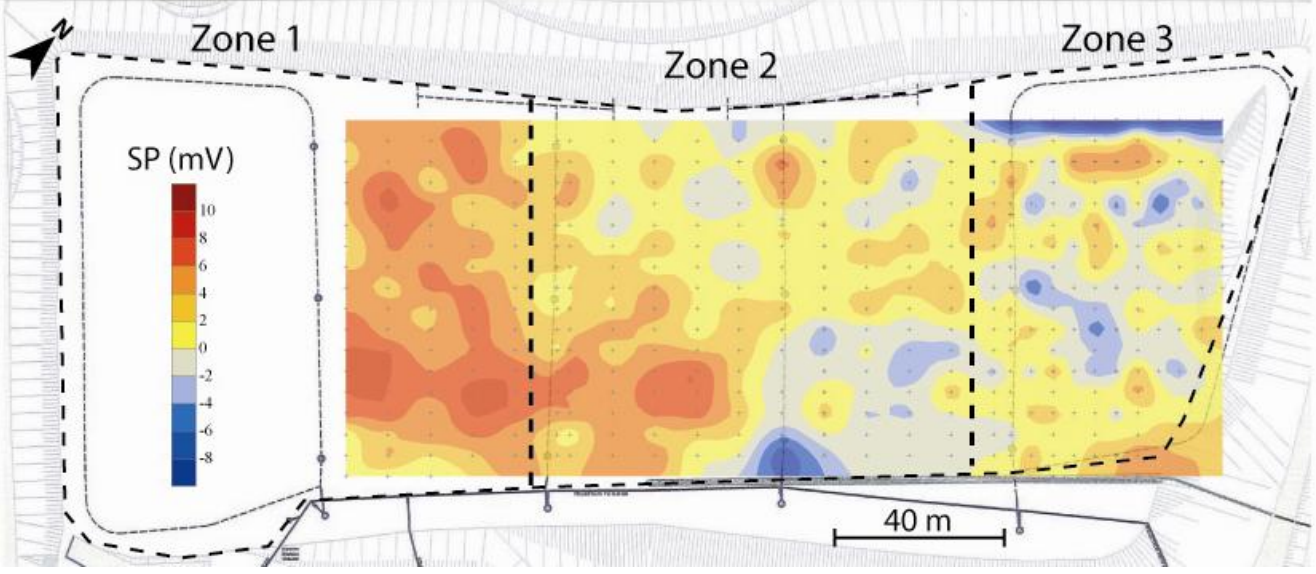

Figure 3. Self-potential map obtained with a point each $10 \mathrm{~m}$

\section{Conclusions}


The Automatic Resistivity Profiling (ARPC) and the Self Potential method (SP) have been applied on an old French landfill in order to better characterize its covering in terms of different material used and in terms of heterogeneities that could be linked to possible defects in the cover due to fractures or cracks. Knowledge of these defects location is important because they can induce preferential water pathways and unusual increase of leachate within the waste mass. Results have shown that the ARP method can clearly locate geodrains as resistive bodies. Both the ARP and SP methods have also outlined three zones that have been covered at different dates. Local differences in apparent resistivity and self-potential signals have also been identified and could result in default in the clay cover due to thickness variations but also in different lithology, compaction and water content. To discriminate these different causes, intrusive geotechnical measurements or geophysical experiments on controlled parcels must be performed

\section{Acknowledgements}

The CALITOM public service union is thanked for assess to the site. Financial supports by ADEME, HydroInvest and the Association Nationale Recherche Technologie (ANRT) through a PhD grant to F. Genelle are acknowledged.

\section{References}

Carpenter, P.J., Calkin, S.F. and Kaufmann, R.S. [1991]. Assessing a fractured landfill cover using electrical resisitivty and seismic refraction techniques. Geophysics, 56 (13), 1896-1904.

Cassiani, G., Fusi, N., Susanni, D. and Deiana. R. [2008] Vertical radar profiling for the assessment of landfill capping effectiveness. Near Surface Geophysics, 6, 133-142.

Dabas, M. [2009] Theroy and practice of the new fast electrical imaging system ARP@), Geophysics and Landscape Archaeology, 105-126.

Guérin, R., Munoz, M.I., Aran, C., Laperelle, C., Hidra, M., Drouart, E. and Grellier, S. [2004] Leachate recirculation: moisture content assessment by means of geophysical technique. Water Management, 24(8): 785-794.

Guyonnet, D., Gourry, J.-C., Bertrand, L. and Amraoui, N. [2003] Heterogeneity detection in an experimental clay liner. Can. Geotech. J. 40, 149-160.

Jouniaux, L., Maineult, A., Naudet, V., Pessel, M., and Sailhac, P. [2009] Review of self-potential methods in hydrogeophysics, Comptes Rendus Geosciences, 341(10-11), 928-936.

Naudet, V., Revil, A., Rizzo, E., Bottero, J.-Y. and Bégassat, P. [2004] Ground water redox conditions and conductivity in a contaminant plume from geoelectrical investigations, Hydrology and Earth System Sciences, 8(1), 8 - 22.

White, C.C. and Barker, R.D. [1997] Electrical leak detection system for landfill liners: a case history, GWMR, 153-159. 